University of Nebraska - Lincoln

DigitalCommons@University of Nebraska - Lincoln

Publications from USDA-ARS / UNL Faculty

U.S. Department of Agriculture: Agricultural

Research Service, Lincoln, Nebraska

2015

\title{
Effect of turning frequency and season on composting materials from swine high-rise facilities
}

\author{
$\mathrm{K}$ L. Cook \\ USDA-ARS, Food Animal Environmental Systems Research Unit \\ E L. Ritchey \\ University of Kentucky, Plant and Soil Sciences \\ $\mathrm{J} \mathrm{H}$. Loughrin \\ USDA-ARS, Food Animal Environmental Systems Research Unit \\ M Haley \\ USDA-ARS, Food Animal Environmental Systems Research Unit, \\ K R. Sistani \\ USDA-ARS, Food Animal Environmental Systems Research Unit,
}

See next page for additional authors

Follow this and additional works at: https://digitalcommons.unl.edu/usdaarsfacpub

Part of the Environmental Monitoring Commons

Cook, K L.; Ritchey, E L.; Loughrin, J H.; Haley, M; Sistani, K R.; and Bolster, C H., "Effect of turning frequency and season on composting materials from swine high-rise facilities" (2015). Publications from USDA-ARS / UNL Faculty. 1498.

https://digitalcommons.unl.edu/usdaarsfacpub/1498

This Article is brought to you for free and open access by the U.S. Department of Agriculture: Agricultural Research Service, Lincoln, Nebraska at DigitalCommons@University of Nebraska - Lincoln. It has been accepted for inclusion in Publications from USDA-ARS / UNL Faculty by an authorized administrator of DigitalCommons@University of Nebraska - Lincoln. 
Authors

K L. Cook, E L. Ritchey, J H. Loughrin, M Haley, K R. Sistani, and C H. Bolster 


\title{
Effect of turning frequency and season on composting materials from swine high-rise facilities
}

\author{
K.L. Cook ${ }^{a, *}$, E.L. Ritchey ${ }^{\mathrm{b}}$, J.H. Loughrin ${ }^{\mathrm{a}}$, M. Haley ${ }^{\mathrm{a}, 1}$, K.R. Sistani ${ }^{\mathrm{a}}$, C.H. Bolster ${ }^{\mathrm{a}}$ \\ ${ }^{a}$ USDA-ARS, Food Animal Environmental Systems Research Unit, Bowling Green, KY, USA \\ ${ }^{\mathrm{b}}$ University of Kentucky, Plant and Soil Sciences, Lexington, KY, USA
}

\section{A R T I C L E I N F O}

\section{Article history:}

Received 15 September 2014

Accepted 10 February 2015

Available online 6 March 2015

\section{Keywords:}

Compost

Nitrogen

Nitrifier

Swine

Slurry

Waste management

\begin{abstract}
A B S T R A C T
Composting swine slurries has several advantages, liquid slurries are converted to solids at lower moisture, the total volume and weight of material is reduced and the stabilized product is more easily transported off-site. Despite this, swine waste is generally stored, treated and applied in its liquid form. High-rise finishing facilities (HRFF) permit liquid slurries to be converted to solids which are partially decomposed underneath the HRFF and then finished in compost windrows. The purpose of this study was to evaluate the effect of turning frequency and ambient weather conditions on biological, physical and chemical properties of composted slurry-woodchip mixtures from HRFF. Compost trials were conducted in either fall (FT) or spring (ST) and piles were turned once or three times per week or upon compost temperature reaching $65^{\circ} \mathrm{C}$. Physical, chemical and microbiological characteristics were measured over the course of 112 (FT) or 143 (ST) days of composting. Total carbon, total nitrogen (N) and inorganic $\mathrm{N}$ decreased in all piles. Ammonium decreased while nitrate increased in all piles (including unturned), but total $\mathrm{N}$ losses were greatest in piles turned more frequently during the ST. Microbial populations of nitrifiers were dominated by ammonia-oxidizing archaea $\left(3.0 \times 10^{3}-4.2 \times 10^{6} \mathrm{cells} \mathrm{g}^{-1}\right.$ compost) but ammonia oxidizing bacteria (below detection to $6.0 \times 10^{5}$ cells g $^{-1}$ compost) varied in response to turning and compost temperature; denitrifiers were present in high concentrations throughout the process. Swine HRFF materials composted well in windrows regardless of turning frequency and despite significant differences in starting materials and low initial C/N. Volume reduction, low moisture and low readily degradable organic matter suggest that the finished compost would have lower transportation costs and should provide value as a soil conditioner.
\end{abstract}

Published by Elsevier Ltd.

\section{Introduction}

In the United States (U.S.) swine slurry, a mixture of feces, urine and wash water, is normally stored in deep pits beneath the facility or in lagoons located adjacent to confinement areas (Key et al., 2011). The stored slurry is spread on nearby crop and pasture lands by irrigation, surface application or injection. The manure is a valuable resource for crop fertilization and soil conditioning. However, in areas with high livestock density, manure production may

Abbreviations: HRFF, high-rise finishing facility; FT, fall trial; ST, spring trial. * Corresponding author at: 230 Bennett Lane, Bowling Green, KY 42104, USA. Tel.: +1 270781 2579; fax: +1 2707817994 .

E-mail addresses: kim.cook@ars.usda.gov (K.L. Cook), Edwin.ritchey@uky.edu (E. L. Ritchey), john.loughrin@ars.usda.gov (J.H. Loughrin), marty.haley@ky.usda.gov (M. Haley), karamat.sistani@ars.usda.gov (K.R. Sistani), carl.bolster@ars.usda.gov (C. H. Bolster).

${ }^{1}$ Current address: Marshall County Service Center, 107 W 5[th] St, Ste A, Benton, KY, USA. outpace land available for application resulting in increases in manure application intensity and the potential for negative environmental impacts (i.e., release of excess nutrients or green house gases, accumulation of salts, growth of deleterious microorganisms). Application of slurry on land in these areas is often restricted and alternative disposal technologies are being evaluated (Aita et al., 2012; Key et al., 2011; Larney et al., 2007; Ten Hoeve et al., 2014).

Composting is an aerobic biological degradation process that decreases manure volume and results in a stable end product that costs less to transport. It is a readily accepted and commonly utilized technique for treating waste materials and has been studied extensively as a manure management tool (recently reviewed by Bernal et al. (2009)). When applied to agricultural land, compost has been shown to improve soil quality (i.e., increased soil organic matter, aggregate stability and drought tolerance) and act as a slow release fertilizer (Bernal et al., 2009; Bustamante et al., 2008; 
Eghball et al., 2004; Lee et al., 2006). Recent research on swine slurry composting and its application to agricultural soils has provided new insights into how swine slurry compost management (turning, moisture, bulking material, temperature, etc.) affects nitrogen dynamics (Angnes et al., 2013; Fukumoto et al., 2009), green house gas emissions (Fukumoto et al., 2003; Selvam et al., 2012; Zhong et al., 2013), pharmaceuticals (Derby et al., 2011) and microbial populations (Kuok et al., 2012; Mc Carthy et al., 2011; Pan et al., 2013).

Despite the proven economic and environmental advantages of composting, the process has not been widely applied for manure management on large scale swine production facilities in the U.S. In fact, the percentage of producers spreading solid swine manure declined $30 \%$ over ten years with $96 \%$ of swine raised on farms using either pits or lagoon systems (Key et al., 2011). The high volume and liquid nature of swine slurry and the requirement for a ready supply of low cost, high carbon (C) bulking material to absorb liquid have limited its application on large scale swine production facilities in the U.S. (USEPA, 2004). However, as livestock intensification trends continue and nutrient application regulations and transportation costs increase, composting should become a more appealing option for manure management at these facilities.

In the past two decades, swine high-rise finishing facilities (HRFF) have been evaluated as an alternative to liquid slurry management systems (Frederick et al., 2002; Keener et al., 2001; Stowell, 2002). In HRFF, the production area is on the second floor (3.5 $\mathrm{m}$ above ground) while the first floor is used for manure management. Woodchips, straw or cornstalks act as a bulking material for aeration and to absorb liquids from wash water, manure, urine and spilt feed that falls through the slatted floor of the living area above. These systems are not common in the U.S. but past studies have found them to be environmentally and economically viable with swine performance on par with traditional facilities (Frederick et al., 2002; Stowell, 2002). The slurry-bulking material mixtures are partially decomposed under the house, but must be finished in windrows outside of the facility. Frederick (2002) showed that composting partially decomposed slurry-bulking materials from HRFF substantially reduced manure volume (62$63 \%$ ) in comparison to deep-pit finishing systems. However, those studies did not evaluate the effect of composting parameters (i.e., turning schedule, environment, or variability in starting material) on finishing partially decomposed materials from swine HRFF. Therefore the purpose of this study was to investigate the effect of turning frequency and compost conditions on biological and physicochemical properties of decomposed swine slurry-woodchip mixtures from a functional HRFF.

\section{Materials and methods}

\subsection{Compost material, study design and sampling}

Decomposed materials (a mixture of swine slurry and woodchips) were obtained on two separate occasions from a swine HRFF located in western Kentucky. The HRFF houses between 4000 and 4800 swine which are placed in the facility at $18-20 \mathrm{~kg}$ and are removed after three months (weighing about $105 \mathrm{~kg}$ ). The high-rise floor raises the living area $3.7 \mathrm{~m}$ above the ground. Manure, excess feed, water and wastewater drop through slatted floors into $2.5 \mathrm{~cm}$ screened woodchips (average size $1.9 \pm 0.9 \mathrm{~cm}$ ). The slurry-woodchip material was turned up to three times per week while under the HRFF. When the material was visibly moist, reducing its ability to absorb additional waste materials, it was removed from the facility for finishing in windrows. In fall 2011 (FT) and Spring 2012 (ST), HRFF slurry-woodchip mix (approximately $60 \mathrm{~m}^{3}$ weighing $48.4 \mathrm{Mg}$ ) was brought by semitrailer trucks to the Western Kentucky University Agricultural Complex where materials were divided into three or four windrow piles. In the FT, swine slurry-woodchip mixes having a bulk density of $849.6 \mathrm{~kg} \mathrm{~m}^{-3}$ and consisting of around $19.6 \mathrm{~m}^{3}$ of material were formed into three piles of approximately $10.4 \mathrm{~m} \times 2.1 \mathrm{~m} \times 0.9 \mathrm{~m}$ $(L \times W \times H)$. In the ST, swine slurry-woodchip mixes having a bulk density of $778.4 \mathrm{~kg} \mathrm{~m}^{-3}$ and consisting of around $18.8 \mathrm{~m}^{3}$ of material were formed into three piles of approximately $5.8 \mathrm{~m} \times 2.7 \mathrm{~m} \times 1.2 \mathrm{~m}(L \times W \times H)$ and a fourth batch (unturned) was left piled at the side $\left(0 \times ; 3.6 \mathrm{~m}^{3}\right)$. In each study, piles were turned using a windrow compost turner (Model CT-10, $\mathrm{HCl}$ Machine Works, Dos Palos, CA) either once per week $(1 \times)$, three times per week $(3 \times)$ or upon the internal compost temperature reaching $65^{\circ} \mathrm{C}$ (@65). Compost for the FT @65 treatment heated to $65^{\circ} \mathrm{C}$ by day 14 and was turned 11 times over the course of the trial. However, during the ST, the @65 pile did not heat for the first 63 days (mean temperature $27 \pm 8^{\circ} \mathrm{C}$ ) therefore weekly turning was initiated at that time. Following recommendations of Tiquia et al. (2000), who found that that statistically valid data were obtained from triplicate composite compost samples taken from different locations within a single windrow pile, data were replicated in this study by visually dividing the compost piles into three sections and taking five composite cores from each section. Compost samples were taken by digging into the pile $15 \mathrm{~cm}$ and using a soil corer to take $15 \mathrm{~cm}$ compost cores from each section. The five composite cores collected from each section were combined to make one replicate for a total of three replicates from each pile. The cores were mixed thoroughly before sub-samples were taken for microbiological and chemical analyses. A separate corer was used for each treatment and corers were sterilized with 70\% ethanol between replicates. Samples were taken on days 0 and three and then weekly for the first 12 weeks and bi-weekly until composting was stopped at day 112 for the FT and day 142 for the ST. Initial characteristics of HRFF slurry-woodchip mixes used for windrow composting are shown in Tables 1 and 2 .

\subsection{Physical and chemical analysis}

Compost temperature was monitored at one hour intervals at three different locations in each pile by $\mathrm{HOBO}^{\circledR}$ Pro V2 temperature sensors (Onset Computer Corp., Bourne, MA, USA). Data on ambient weather conditions (temperature, precipitation) were obtained from the Kentucky Mesonet weather station (Warren County, Kentucky Mesonet, http://www.kymesonet.org, accessed Jan. 2015 ) located within $15 \mathrm{~m}$ of the compost site. Physical and chemical characteristics of compost samples were measured as previously described (Sistani et al., 2010). Briefly, dry weight of compost samples was determined after drying $24 \mathrm{~h}$ at $105^{\circ} \mathrm{C}$. Composite compost samples were analyzed for ammonium nitrogen $\left(\mathrm{NH}_{4}-\mathrm{N}\right)$, and nitrate nitrogen $\left(\mathrm{NO}_{3}-\mathrm{N}\right)$ after extraction with $2 \mathrm{M}$ $\mathrm{KCl}$ ((Kenney et al., 1982); 1:10 soil: $\mathrm{KCl}$ extraction ratio) using flow injection analysis (QuickChem FIA+, Lachat Instruments, Milwaukee, WI). Total nitrogen (TN) and total carbon (TC) in the soil were measured using a Vario Max $\mathrm{CN}$ analyzer (Elementar Americas, Mt. Laurel, NJ). The remaining elements were measured using inductively coupled plasma-optical emission spectroscopy (ICP-OES; Vista-Pro Axial; Agilent Technologies, Santa Clara, CA) after microwave digestion with $\mathrm{HNO}_{3}$ and $\mathrm{HCl}$. The $\mathrm{pH}$ of compost samples was measured using a $1: 1(\mathrm{w} / \mathrm{v})$ compost to water solution using a combination electrode (Accuphast electrode, Fisher Scientific, Pittsburg, PA). Percent change between the initial and final nutrient (element) concentration was determined by ((Final concentration - initial concentration)/initial) $* 100)$. A positive value indicated an increase in concentration and a negative value indicated a decrease in concentration. 
Table 1

Initial and final compost physicochemical parameters.

\begin{tabular}{|c|c|c|c|c|c|c|c|c|c|c|}
\hline \multirow[t]{2}{*}{ Treatment } & \multirow[t]{2}{*}{$\mathrm{pH}$} & Moisture & $\mathrm{OM}^{\mathrm{a}}$ & \multirow[t]{2}{*}{ Humic acid } & \multirow[t]{2}{*}{$\mathrm{C} / \mathrm{N}$ ratio } & Total C & Total $\mathrm{N}$ & $\mathrm{NH}_{4}-\mathrm{N}$ & $\mathrm{NO}_{3}-\mathrm{N}$ & $\% \mathrm{IN}^{\mathrm{b}}$ \\
\hline & & $\%$ & & & & \multicolumn{5}{|l|}{$\mathrm{g} \mathrm{kg}^{-1}$} \\
\hline \multicolumn{11}{|l|}{ Fall trial ${ }^{c}$} \\
\hline Initial & $7.69 \pm 0.11 \mathrm{~A}$ & $49.44 \pm 0.13 \mathrm{~A}$ & $47.96 \pm 0.57 \mathrm{~A}$ & $9.04 \pm 0.66$ & 12.09 & $278.81 \pm 3.31 \mathrm{~A}$ & $23.06 \pm 0.08 \mathrm{~A}$ & $3.22 \pm 0.08 \mathrm{~A}$ & $0.04 \pm 0.01 \mathrm{~B}$ & 14.14 \\
\hline One time & $6.87 \pm 0.09 \mathrm{~A}$ & $42.00 \pm 2.75 \mathrm{~B}$ & $42.84 \pm 2.03 \mathrm{~A}$ & $9.33 \pm 0.32$ & 11.09 & $249.07 \pm 11.82 \mathrm{~A}$ & $22.45 \pm 1.33 \mathrm{~A}$ & $0.31 \pm 0.11 \mathrm{~A}$ & $0.92 \pm 0.30 \mathrm{~A}$ & 5.48 \\
\hline Three time & $6.63 \pm 0.06 \mathrm{~A}$ & $44.13 \pm 2.38 \mathrm{~B}$ & $45.29 \pm 3.55 \mathrm{~B}$ & $8.85 \pm 0.22$ & 11.35 & $263.30 \pm 20.61 \mathrm{~B}$ & $23.20 \pm 1.32 \mathrm{~B}$ & $0.11 \pm 0.05 \mathrm{~A}$ & $1.25 \pm 0.17 \mathrm{~B}$ & 5.86 \\
\hline At $65^{\circ} \mathrm{C}$ & $7.59 \pm 0.03 \mathrm{~A}$ & $32.16 \pm 0.14 \mathrm{~A}$ & $41.86 \pm 0.43 \mathrm{~A}$ & $9.23 \pm 0.56$ & 10.45 & $243.37 \pm 2.49 \mathrm{~A}$ & $23.28 \pm 0.37 \mathrm{~A}$ & $1.10 \pm 0.11 \mathrm{~B}$ & $0.20 \pm 0.03 \mathrm{~A}$ & 5.58 \\
\hline \multicolumn{11}{|l|}{ Spring trial ${ }^{\mathrm{d}}$} \\
\hline Initial & $8.04 \pm 0.18 \mathrm{~B}$ & $57.06 \pm 0.13 \mathrm{~B}$ & $57.07 \pm 6.05 \mathrm{~A}$ & $9.95 \pm 0.26$ & 10.71 & $331.79 \pm 35.15 \mathrm{~A}$ & $31.03 \pm 3.89 \mathrm{~B}$ & $5.24 \pm 0.10 \mathrm{~B}$ & $0.01 \pm 0.00 \mathrm{~A}$ & 16.92 \\
\hline One time & $7.75 \pm 0.09 \mathrm{~B}$ & $30.64 \pm 1.23 \mathrm{~A}$ & $46.92 \pm 4.19 \mathrm{~B}$ & $5.62 \pm 0.43$ & 10.82 & $272.82 \pm 24.38$ B & $25.22 \pm 1.57 \mathrm{~A}$ & $0.12 \pm 0.07 \mathrm{~A}$ & $1.83 \pm 0.22 \mathrm{~A}$ & 7.73 \\
\hline Three time & $7.76 \pm 0.04 \mathrm{~B}$ & $25.68 \pm 2.95 \mathrm{~A}$ & $37.90 \pm 0.32 \mathrm{~A}$ & $5.61 \pm 1.31$ & 11.40 & $220.35 \pm 1.87 \mathrm{~A}$ & $19.33 \pm 0.22 \mathrm{~A}$ & $0.02 \pm 0.01 \mathrm{~A}$ & $0.98 \pm 0.09 \mathrm{~B}$ & 5.17 \\
\hline At $65^{\circ} \mathrm{C}$ & $7.80 \pm 0.04 \mathrm{~B}$ & $37.19 \pm 0.49 \mathrm{~B}$ & $44.89 \pm 2.63 \mathrm{~A}$ & $5.10 \pm 0.41$ & 10.90 & $260.97 \pm 15.30 \mathrm{~A}$ & $23.94 \pm 2.07 \mathrm{~A}$ & $0.29 \pm 0.18 \mathrm{~B}$ & $1.34 \pm 0.16 \mathrm{~B}$ & 6.81 \\
\hline \multirow[t]{2}{*}{ No turn } & $7.72 \pm 0.07$ & $58.07 \pm 3.19$ & $56.75 \pm 3.99$ & $6.81 \pm 0.62$ & 10.36 & $329.93 \pm 23.20$ & $31.84 \pm 4.65$ & $0.34 \pm 0.42$ & $2.09 \pm 0.58$ & 7.63 \\
\hline & \multicolumn{10}{|c|}{ Percent change in initial values after composting ${ }^{e}$} \\
\hline \multicolumn{11}{|l|}{ Fall trial $^{\mathrm{C}}$} \\
\hline One time & $-10.7 \mathrm{~b}$ & $-15.0 \mathrm{~b}$ & $-10.7 \mathrm{a}$ & +3.2 & -8.3 & $-10.7 \mathrm{a}$ & $-2.6 \mathrm{a}$ & $-90.4 \mathrm{~b}$ & $+2200 \mathrm{~b}$ & -61.4 \\
\hline Three time & $-13.8 \mathrm{a}$ & $-10.7 \mathrm{~b}$ & $-5.6 \mathrm{a}$ & -2.1 & -6.1 & $-5.6 \mathrm{a}$ & $+0.6 \mathrm{a}$ & $-96.6 \mathrm{a}$ & $+3025 \mathrm{c}$ & -58.6 \\
\hline At $65^{\circ} \mathrm{C}$ & $-1.3 \mathrm{c}$ & $-35.0 \mathrm{a}$ & $-12.7 \mathrm{a}$ & +2.1 & -13.6 & $-12.7 \mathrm{a}$ & $+0.9 \mathrm{a}$ & $-65.8 c$ & +400 a & -60.5 \\
\hline \multicolumn{11}{|l|}{ Spring trial ${ }^{\mathrm{d}}$} \\
\hline One time & $-3.6 \mathrm{a}$ & $-46.3 \mathrm{~b}$ & $-17.8 \mathrm{~b}$ & -43.5 & +1.0 & $-17.8 \mathrm{~b}$ & $-18.7 \mathrm{~b}$ & $-97.7 \mathrm{a}$ & $+18,200 \mathrm{c}$ & -54.3 \\
\hline Three time & $-3.5 \mathrm{a}$ & $-55.0 \mathrm{a}$ & $-33.6 \mathrm{a}$ & -43.6 & +6.4 & $-33.6 \mathrm{a}$ & $-37.7 \mathrm{a}$ & $-99.6 \mathrm{a}$ & $+9700 \mathrm{a}$ & -69.4 \\
\hline At $65^{\circ} \mathrm{C}$ & $-3.0 \mathrm{a}$ & $-34.8 c$ & $-21.3 \mathrm{~b}$ & -48.7 & +1.8 & $-21.3 \mathrm{~b}$ & $-22.8 \mathrm{~b}$ & $-94.4 \mathrm{a}$ & $+13,300 \mathrm{~b}$ & -60.0 \\
\hline No turn & $-4.0 \mathrm{a}$ & $+1.8 \mathrm{~d}$ & $-0.6 \mathrm{c}$ & -31.6 & -3.3 & $-0.6 \mathrm{c}$ & $+2.6 \mathrm{c}$ & $-93.5 \mathrm{a}$ & $+20,800 \mathrm{c}$ & -54.9 \\
\hline
\end{tabular}

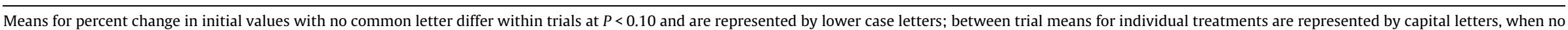
common letter is present they differ by $P<0.10$.

a $\mathrm{OM}=$ organic matter; total organic carbon $(\%) \times 1.72$; conversion factor assumes organic matter contains $58 \%$ organic carbon.

${ }^{b}$ IN = inorganic $\mathrm{N}$; \% IN of total $\mathrm{N}=\left(\left(\mathrm{NH}_{4}-\mathrm{N}+\mathrm{NO}_{3}-\mathrm{N}\right) / \text { Total } \mathrm{N}\right)^{*} 100$.

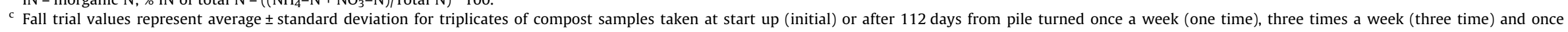
temperature reached $65^{\circ} \mathrm{C}\left(\right.$ at $\left.65^{\circ} \mathrm{C}\right)$.

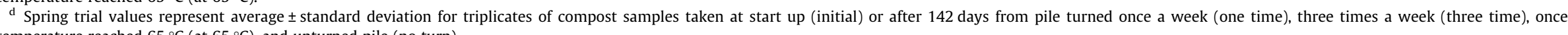
temperature reached $65^{\circ} \mathrm{C}\left(\right.$ at $65^{\circ} \mathrm{C}$ ), and unturned pile (no turn).

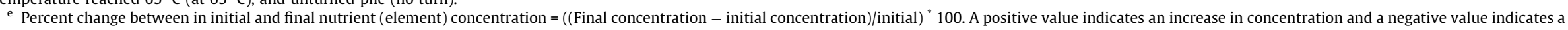
decrease in concentration. 
Table 2

Initial and final chemical properties.

\begin{tabular}{|c|c|c|c|c|c|c|c|c|c|}
\hline \multirow[t]{2}{*}{ Treatment } & $\mathrm{P}$ & $\mathrm{K}$ & $\mathrm{Al}$ & $\mathrm{Ca}$ & $\mathrm{Fe}$ & $\mathrm{Mg}$ & $\mathrm{Na}$ & $\mathrm{S}$ & $\mathrm{Zn}$ \\
\hline & \multicolumn{9}{|l|}{$\mathrm{g} \mathrm{kg}^{-1}$} \\
\hline \multicolumn{10}{|l|}{ Fall trial $^{\mathrm{a}}$} \\
\hline Initial & $17.22 \pm 1.05$ & $21.32 \pm 1.19$ & $11.27 \pm 0.45$ & $58.16 \pm 8.37$ & $13.44 \pm 1.20$ & $11.19 \pm 0.58$ & $5.55 \pm 0.36$ & $7.76 \pm 0.45$ & $0.72 \pm 0.08$ \\
\hline $1 \times$ & $20.30 \pm 0.64$ & $20.32 \pm 2.07$ & $17.08 \pm 1.72$ & $53.48 \pm 8.37$ & $15.99 \pm 1.07$ & $12.01 \pm 0.30$ & $5.17 \pm 1.13$ & $7.68 \pm 0.25$ & $0.82 \pm 0.06$ \\
\hline $3 \times$ & $19.02 \pm 1.05$ & $19.96 \pm 1.03$ & $15.82 \pm 1.43$ & $47.04 \pm 2.66$ & $15.75 \pm 1.60$ & $11.29 \pm 0.10$ & $5.30 \pm 0.50$ & $7.51 \pm 0.22$ & $0.77 \pm 0.04$ \\
\hline @65 & $19.43 \pm 0.99$ & $20.24 \pm 0.82$ & $15.27 \pm 1.24$ & $62.83 \pm 3.10$ & $14.91 \pm 1.86$ & $11.69 \pm 0.73$ & $5.40 \pm 0.25$ & $7.40 \pm 0.33$ & $0.76 \pm 0.03$ \\
\hline \multicolumn{10}{|l|}{ Spring trial ${ }^{\mathrm{b}}$} \\
\hline Initial & $21.57 \pm 2.24$ & $26.33 \pm 2.25$ & $7.79 \pm 1.13$ & $32.90 \pm 4.45$ & $8.84 \pm 0.87$ & $12.05 \pm 1.28$ & $9.92 \pm 0.88$ & $10.34 \pm 0.96$ & $0.97 \pm 0.11$ \\
\hline $1 \times$ & $24.61 \pm 1.12$ & $32.62 \pm 1.33$ & $14.28 \pm 1.92$ & $43.27 \pm 1.06$ & $15.06 \pm 0.43$ & $13.26 \pm 0.70$ & $10.84 \pm 0.57$ & $12.86 \pm 0.89$ & $1.17 \pm 0.04$ \\
\hline $3 \times$ & $18.92 \pm 1.26$ & $27.51 \pm 2.33$ & $20.41 \pm 1.48$ & $40.05 \pm 4.49$ & $18.74 \pm 1.78$ & $11.36 \pm 0.77$ & $8.85 \pm 0.85$ & $10.42 \pm 1.08$ & $0.94 \pm 0.03$ \\
\hline @65 & $22.22 \pm 0.66$ & $29.88 \pm 0.96$ & $14.13 \pm 1.78$ & $38.93 \pm 0.97$ & $14.64 \pm 1.72$ & $11.77 \pm 0.33$ & $9.93 \pm 0.50$ & $11.96 \pm 0.36$ & $1.07 \pm 0.05$ \\
\hline $0 \times$ & $28.73 \pm 1.46$ & $32.94 \pm 2.45$ & $11.37 \pm 1.33$ & $45.29 \pm 1.60$ & $16.75 \pm 6.94$ & $14.83 \pm 1.19$ & $10.72 \pm 0.90$ & $13.41 \pm 1.03$ & $1.27 \pm 0.04$ \\
\hline
\end{tabular}

Percent change in initial values after composting

\begin{tabular}{|c|c|c|c|c|c|c|c|c|c|}
\hline \multicolumn{10}{|c|}{ Fall trial $^{\mathrm{a}}$} \\
\hline $1 \times$ & $+18.0 \mathrm{a}$ & $-4.7 \mathrm{a}$ & $+51.6 \mathrm{~b}$ & $-8.1 \mathrm{a}$ & $+19.4 \mathrm{a}$ & $+7.1 \mathrm{a}$ & $-7.7 \mathrm{a}$ & $-1.3 \mathrm{a}$ & $+13.9 \mathrm{a}$ \\
\hline $3 \times$ & $+10.5 \mathrm{a}$ & $-6.1 \mathrm{a}$ & $+40.4 \mathrm{ab}$ & $-19.2 \mathrm{a}$ & $+17.9 \mathrm{a}$ & $+0.9 \mathrm{a}$ & $-5.4 \mathrm{a}$ & $-3.8 \mathrm{a}$ & $+6.9 \mathrm{a}$ \\
\hline @65 & $+12.8 \mathrm{a}$ & $-5.2 \mathrm{a}$ & $+35.5 \mathrm{a}$ & $+7.9 \mathrm{~b}$ & $+11.2 \mathrm{a}$ & $+4.5 \mathrm{a}$ & $-3.6 \mathrm{a}$ & $-5.1 \mathrm{a}$ & $+5.6 \mathrm{a}$ \\
\hline \multicolumn{10}{|c|}{ Spring trial ${ }^{\mathrm{b}}$} \\
\hline $1 \times$ & $+14.0 \mathrm{~b}$ & $+24.0 \mathrm{bc}$ & $+83.3 \mathrm{~b}$ & $+31.5 \mathrm{ab}$ & $+70.6 \mathrm{ab}$ & +10.1 bc & $+8.5 \mathrm{~b}$ & +24.6 bc & +20.9 bc \\
\hline $3 \times$ & $-12.4 \mathrm{a}$ & $+4.6 \mathrm{a}$ & $+162.0 \mathrm{c}$ & $+21.5 \mathrm{ab}$ & $+111.3 \mathrm{~b}$ & $-5.6 \mathrm{a}$ & $-10.6 \mathrm{a}$ & $+0.5 \mathrm{a}$ & $-2.8 \mathrm{a}$ \\
\hline @65 & $+2.9 \mathrm{~b}$ & $+13.7 \mathrm{ab}$ & $+81.4 \mathrm{~b}$ & $+18.1 \mathrm{a}$ & $+65.0 \mathrm{a}$ & $+2.3 \mathrm{ab}$ & $-0.5 \mathrm{ab}$ & +15.9 b & $+10.6 \mathrm{~b}$ \\
\hline $0 \times$ & $+33.0 \mathrm{c}$ & $+25.1 \mathrm{c}$ & $+46.0 \mathrm{a}$ & $+37.6 \mathrm{~b}$ & $+88.7 \mathrm{ab}$ & $+22.6 \mathrm{c}$ & $+7.5 \mathrm{~b}$ & $+29.5 \mathrm{c}$ & $+31.3 c$ \\
\hline
\end{tabular}

Means within an element with no common letter differ at $p<0.10$.

a Fall trial values represent average \pm standard deviation for triplicates of compost samples taken at start up (initial) or after 112 days from pile turned once a week $(1 \times$ ), three times a week $(3 \times)$ and once temperature reached $65{ }^{\circ} \mathrm{C}(@ 65)$.

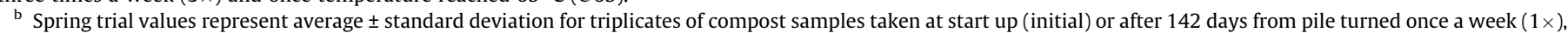
three times a week $(3 \times)$ and once temperature reached $65{ }^{\circ} \mathrm{C}(@ 65)$, and unturned pile $(0 \times)$.

c Percent change between in initial and final nutrient (element) concentration $=(($ Final concentration - initial concentration $) /$ initial $) * 100$. A positive value indicates an increase in concentration and a negative value indicates a decrease in concentration.

Table 3

Compost temperature thermophilic phase.

\begin{tabular}{lllll}
\hline Treatment & $\begin{array}{l}\text { Peak }^{\mathrm{a}} \\
\left({ }^{\circ} \mathrm{C}\right)\end{array}$ & TP & $\mathrm{TT}^{\mathrm{c}}$ & $\mathrm{DT}^{\mathrm{d}}$ \\
\cline { 3 - 5 } & & & & \\
\hline Fall Trial & 72 & 26 & 2 & 47 \\
One time & 68 & 14 & 4 & 38 \\
Three time & 62 & 18 & 3 & 42 \\
At $65^{\circ} \mathrm{C}$ & & & & \\
Spring trial & 64 & 33 & 31 & 25 \\
One time & 64 & 56 & 51 & 19 \\
Three time & 62 & 105 & 80 & 62 \\
At $65^{\circ} \mathrm{C}$ & 34 & N/A & N/A & N/A \\
No turn & & & & \\
\hline
\end{tabular}

a Peak temperature.

b Time in days to reach peak temperature.

c Time in days to reach thermophilic temperature.

${ }^{d}$ Duration of thermophilic phase.

\subsection{DNA extraction, DNA purification and real-time PCR analysis}

DNA from composite compost samples (300 mg) was extracted using the FastDNA ${ }^{\circledR}$ Spin kit for soils (MP Biomedical, Solon, OH, USA) according to manufacturer's specifications. DNA extracts were found to be very inhibitory (requiring up to 1000 -fold dilution). Therefore DNA was purified by electrophoresis for $40 \mathrm{~min}$ at $100 \mathrm{~V}$ using $40 \mu \mathrm{l}$ of sample run on a $2 \%$ agarose gel (Fisher Scientific, Pittsburgh, PA) in $1 \times$ TBE (Tris-borate-EDTA) buffer. DNA gel bands visibly separated from humic materials and were excised and purified using the Qiagen QIAquick Gel Extraction Kit (Qiagen, Valencia, CA) as suggested by the manufacturer. The $1: 10$ dilution of gel purified DNA extracts showed no inhibition and was used for all analyses.
Quantitative, real-time PCR (qPCR) was used to target total cells, nitrifying and denitrifying populations. Primers, probes and the qPCR protocols for each assay are shown in Table 4 . In several cases, primers were modified from previously published to accommodate sequences obtained from swine clone libraries and/or if qPCR efficiency was low (i.e., less than $80 \%$ ). Modifications are indicated in bold in Table 4 . The assays were optimized for annealing temperature and efficiency which improved to over 90\%. Taqman assays were carried out in Qiagen HotStarTaq Master Mix and SYBR assays were carried out in QuantiTect SYBR Green PCR mix (Qiagen, Valencia, CA) as previously described (Cook et al., 2014).

\subsection{Statistical analysis}

Data were expressed as means and standard deviations. Statistics were performed using SAS version 9.3 (SAS Institute, 2013). The mixed-model procedure was used for analysis of variance and significant differences among means were determined by the diff option at $p<0.10$. Correlations between compost and ambient temperatures were determined using PROC REG.

\section{Results and discussion}

\subsection{Initial high-rise slurry-woodchip mix characteristics}

Compost for this study was from an operational HRFF that uses woodchips to absorb liquid from manure and wash water generated during animal production. In these systems, liquid slurries are converted to solids as part of the production process. Woodchips are routinely used by this producer since they are cost-effective, readily available through contract with the municipality and the chips are a good source of bulking material for the moist, dense slurry. In a study of bedding options for compost dairy barns, 
Table 4

Quantitative, real-time PCR assays.

\begin{tabular}{|c|c|c|c|c|c|c|}
\hline Organism or group & Target gene & Primer $^{a}$ & Sequence $\left(5^{\prime}-3^{\prime}\right)^{\mathrm{b}}$ & $T_{m}{ }^{\mathrm{c}}\left({ }^{\circ} \mathrm{C}\right)$ & Product $^{\mathrm{d}}(\mathrm{bp})$ & Reference \\
\hline All bacteria & 16S rRNA & $\begin{array}{l}\mathrm{F} \\
\mathrm{R} \\
\mathrm{P}\end{array}$ & $\begin{array}{l}\text { ATG GCT GTC GTC AGC T } \\
\text { ACG GGC GGT GTG TAC } \\
\text { FAM-CAA CGA GCG CAA CCC-BHQ }\end{array}$ & 58 & 337 & Harms et al. (2003) \\
\hline $\begin{array}{l}\text { Nitrifiers } \\
\text { Ammonia oxidizing archaea }\end{array}$ & arch-amoA & $\begin{array}{l}\mathrm{F}^{*} \\
\mathrm{R}\end{array}$ & $\begin{array}{l}\text { CAG GTC GGT AAG TTC TAC AAT AGT CC } \\
\text { GCG GCC ATC CAT CTG TAT GT }\end{array}$ & 56 & 121 & Francis et al. (2005) \\
\hline Ammonia oxidizing bacteria & amoA & $\begin{array}{l}\mathrm{F}^{*} \\
\mathrm{R}^{*} \\
\mathrm{P}\end{array}$ & $\begin{array}{l}\text { TCG GTA GCY GAC TAC ACS GG } \\
\text { CYT TKA CRT AGT AGA AAG CGG } \\
\text { FAM-CCA AAG TAC CAC CAT ACG CAG-BHQ }\end{array}$ & 56 & 205 & Harms et al. (2003) \\
\hline $\begin{array}{l}\text { Denitrifiers } \\
\text { Nitrate reducing bacteria }\end{array}$ & narG & $\begin{array}{l}F^{*} \\
R \\
P\end{array}$ & $\begin{array}{l}\text { GAY TTC CGC ATG AGY AC } \\
\text { TTY TCG TAC CAG GTG GC } \\
\text { FAM-TAY TCC GAC ATC GT-BHQ }\end{array}$ & 60 & 69 & Smith et al. (2007) \\
\hline Nitrite reducing bacteria & nirK & $\begin{array}{l}\mathrm{F} \\
\mathrm{R}\end{array}$ & $\begin{array}{l}\text { ATC ATG GTS CTG CCG CG } \\
\text { GCC TCG ATC AGR TTG TGG TT }\end{array}$ & 57 & 472 & Throback et al. (2004) \\
\hline Nitrous oxide reducing bacteria & $\operatorname{nos} Z$ & $\begin{array}{l}\mathrm{F} \\
\mathrm{R}^{*}\end{array}$ & $\begin{array}{l}\text { CGY TGT TCM TCG ACA GCC AG } \\
\text { CGG TCC TTG GAG AAC TTG }\end{array}$ & 53 & 200 & Throback et al. (2004) \\
\hline
\end{tabular}

\footnotetext{
a Primer designed or modified for this study; $\mathrm{F}=$ forward, $\mathrm{R}=$ reverse, $\mathrm{P}=$ probe.

b Bold base pair denotes modified bases; Probe sequences have a 5' FAM fluorophore and 3' black hole quencher.

c $T_{m}$ is the annealing temperature at which the PCR assay was performed.

d Expected amplification product size in nucleotide basepairs (bp).

* Asterisk indicates that primer was modified.
}

Shane et al. (2010) found that the best materials were those with good physical structure, low initial moisture, less than $2.5 \mathrm{~cm}$ long and were able to maintain structure following mixing. Similar criteria are necessary for amendments in HRFF; in this case woodchips were dry, maintained structure while under the production facility, and the size (average $1.9 \pm 0.9 \mathrm{~cm}$ ) was highly variable making them adequate for both liquid absorption and as bulking agent to supply structure and improve aeration.

Initial nutrient levels and $\mathrm{C} / \mathrm{N}$ ratios of the slurry-woodchip mix used in this study were similar to those of other swine waste composts (Tables 1 and 2; Bustamante et al., 2013; Tiquia et al., 2002; Wang et al., 2013) although initial $\mathrm{C} / \mathrm{N}$ ratio and moisture content were lower than similar products from other HRFF (Table 1; Keener et al., 2001; Stowell, 2002). The initial swine slurry-woodchip mix obtained for the FT and ST differed significantly in terms of $\mathrm{pH}, \mathrm{N}$, ammonium $\left(\mathrm{NH}_{4}^{+}\right)$, phosphorous $(\mathrm{P})$, potassium $(\mathrm{K})$, moisture and $\mathrm{C} / \mathrm{N}$ ratio $(P<0.10)$; likely due to differences in the amount of time the material was maintained under the finishing facility, the amount of bulking material added, frequency of turning and/or seasonal conditions (temperature, moisture, humidity). However, these are differences to be expected within the bounds of normal farm operations in any agricultural setting. Tiquia et al. (2000) also found that swine slurry mixes differed in $\mathrm{C}$ and $\mathrm{N}$ content according to time of year that samples were taken and attributed differences to farm management methods.

\subsection{Variability of temperature, moisture and $\mathrm{pH}$ during the composting process}

Despite differences in both physical and chemical composition of materials composted in the FT and ST, all turned compost piles reached and maintained thermophilic composting temperatures (above $50{ }^{\circ} \mathrm{C}$ ) for between 19 and 62 days (Fig. $1 \mathrm{~A}$ and B). Peak compost temperatures and time to thermophilic conditions occurred earlier for all piles in the FT than in the ST (Table 3). Compost piles used for the FT $\left(19.6 \mathrm{~m}^{3}\right)$ were larger than were piles used for the ST $\left(18.8 \mathrm{~m}^{3}\right)$ possibly accounting for differences in time to reach peak temperature. Tirado et al. (2010) found that larger piles of dairy manure compost had higher average
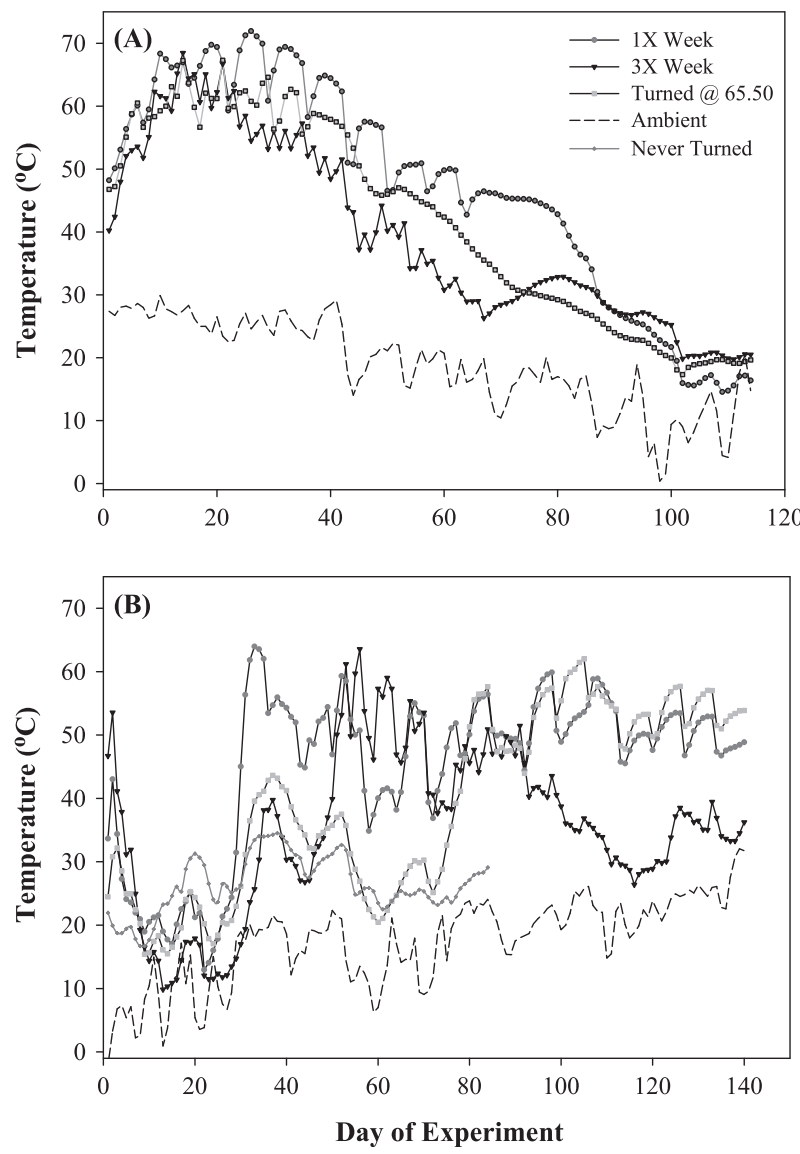

Fig. 1. Temperature profiles for spring (A) or fall (B) compost trials. Values represent the mean of three replicate measurements taken on an hourly basis.

temperatures than smaller piles. However, Tiquia et al. (2002) found that compost temperature was significantly affected by turning and not by compost structure. In this study, the $3 \times$ ST pile 
turned more often required longer to achieve thermophilic temperatures than did the $1 \times$ ST pile although the difference was not as pronounced in the FT (Table 3 ). It is also noteworthy that ambient temperatures during the first 30 days of the FT were the warmest $\left(26.2 \pm 1.9{ }^{\circ} \mathrm{C}\right)$ while the first 30 days of the ST were the coldest $\left(9.1 \pm 5.1{ }^{\circ} \mathrm{C}\right)$. However, studies have shown that composting season does not have a strong effect on the composting process (Ciavatta et al., 1993; Larney et al., 2000; Tiquia et al., 2000) but may be associated with moisture (Tirado et al., 2010) or nutrient loss due to leaching and volatilization (Parkinson et al., 2004).

As a result of the differences in time to reach thermophilic temperatures in this study, the FT was stopped after 112 days while the ST was carried out to 142 days. The delayed heating of all piles in ST also delayed completion of composting and resulted in final compost temperatures that were still above ambient for the $1 \times$ and at $65^{\circ} \mathrm{C}$ piles (Fig. 1B). Composting was stopped in the ST since the $3 \times$ pile had reached ambient temperatures and all piles had reached moisture levels that were not conducive to composting (Table 1). However, the time required to compost these swine waste materials was similar to the time required (126 days) to compost materials from swine deep litter systems that had no moisture adjustment and were turned weekly, but was significantly longer ( 56 days) than piles from the same study that were turned every four days and were maintained at $60 \%$ moisture (Tiquia, 2005).

The initial swine slurry-woodchip mix moisture level was significantly lower for the FT $(49.4 \pm 0.13 \%)$ than for the ST (57.1 $\pm 0.13 \%)$, however, final moisture levels were lower for ST piles turned $1 \times$ or $3 \times$ (Table 1$)$. This was despite the higher precipitation during the ST $(33.4 \mathrm{~cm})$ than during the FT $(30.1 \mathrm{~cm})$. In a study to evaluate the effect of turning on moisture loss from sewage sludge compost, Hong et al. (2014) found that both turning schedule and the phase of composting in which turning occurred influenced final compost moisture. In this study, compost piles that were turned more often in the initial phases of composting had lower final moisture levels at the end of the experiment. For example, in the FT the @65 ${ }^{\circ} \mathrm{C}$ pile had the lowest moisture level and was turned 11 times in the first 4 weeks and was not turned for the next 5 weeks (32\%; Table 1$)$. In the ST, the same pile $\left(@ 65^{\circ} \mathrm{C}\right.$ ) had the highest final moisture (37\%; Table 1) and that pile was not turned for the first 60 days of composting, but was turned 10 times in the following weeks.

The initial $\mathrm{pH}$ in swine slurry-woodchip mixes from the HRFF was generally similar to that reported for other decomposed swine slurry bedding mixes and raw manure compost starting materials (Qian et al., 2014; Tiquia et al., 2002; Tirado et al., 2010). Initial and final $\mathrm{pH}$ in the FT were slightly lower than that in the ST (Table 1). However, $\mathrm{pH}$ decreased with time in all piles as expected (Table 1).

\subsection{Characterization of composted materials: nutrient, carbon and mass change}

In both compost trials concentrations of $\mathrm{Al}, \mathrm{Ca}, \mathrm{Fe}, \mathrm{K}$ and $\mathrm{S}$ increased in all treatments (Table 2). In the FT, there were few differences in nutrient concentrations based on turning frequency $(P<0.10)$. However, in the ST the $3 \times$ pile had greater decreases in $\mathrm{N}, \mathrm{NO}_{3}-\mathrm{N}, \mathrm{P}, \mathrm{Mg}$, and $\mathrm{Zn}$ and had the lowest dry weight (Table 2). Increases were expected due to limited mobility of the compounds and elemental concentration as a result of $\mathrm{CO}_{2}$ evolution and increased dry matter. However, loss of other nutrients in this study were generally lower than in other studies, perhaps due to the low initial $\mathrm{C} / \mathrm{N}$ ratio (Tables 1 and 2; (Nolan et al., 2011; Tiquia et al., 2002)). Nolan et al. (2011) found that the $\mathrm{C} / \mathrm{N}$ ratio did not change significantly when sawdust and woodchips were used as bulking material and suggested that the lignin in the woody materials is more resistant to degradation. Research has also shown that decomposition and nitrogen release may be lower when woodchips are used as amendment rather than sawdust (Sharifi et al., 2014; Wang et al., 2004). Nutrient loss, final nutrient concentration and plant availability have a substantial impact on the value and use of compost as a fertilizer in agricultural applications. Although the value of compost as a soil conditioner (improvement in soil structure, soil organic matter, water retention characteristics) is well established (Eghball et al., 2004; McAndrews et al., 2006), more research is needed to evaluate the costs and benefits of applying finished compost from swine HRFF to row crops.

Ammonical nitrogen was high in the initial HRFF materials (3.22 $\mathrm{g} \mathrm{k}^{-1}$ for FT and $5.24 \mathrm{~g} \mathrm{~kg}^{-1}$ for ST) used in this study, but was in the same range as those found in other livestock composts (Ros et al., 2006; Tiquia et al., 2002; Wang et al., 2013). In this case, high initial $\mathrm{NH}_{4}-\mathrm{N}$ suggests that, in addition to high concentrations in the manure itself, easily degradable OM was being converted to $\mathrm{NH}_{4}-\mathrm{N}$ through ammonification while the slurry-woodchip mix was under the HRFF. Of the TN in the initial slurry-woodchip mix from the HRFF materials used for the FT and ST, $14 \%$ and $17 \%$, respectively was in the form of inorganic-N (IN). At the end of the compost trials IN losses were between $54 \%$ and $70 \%$ of initial
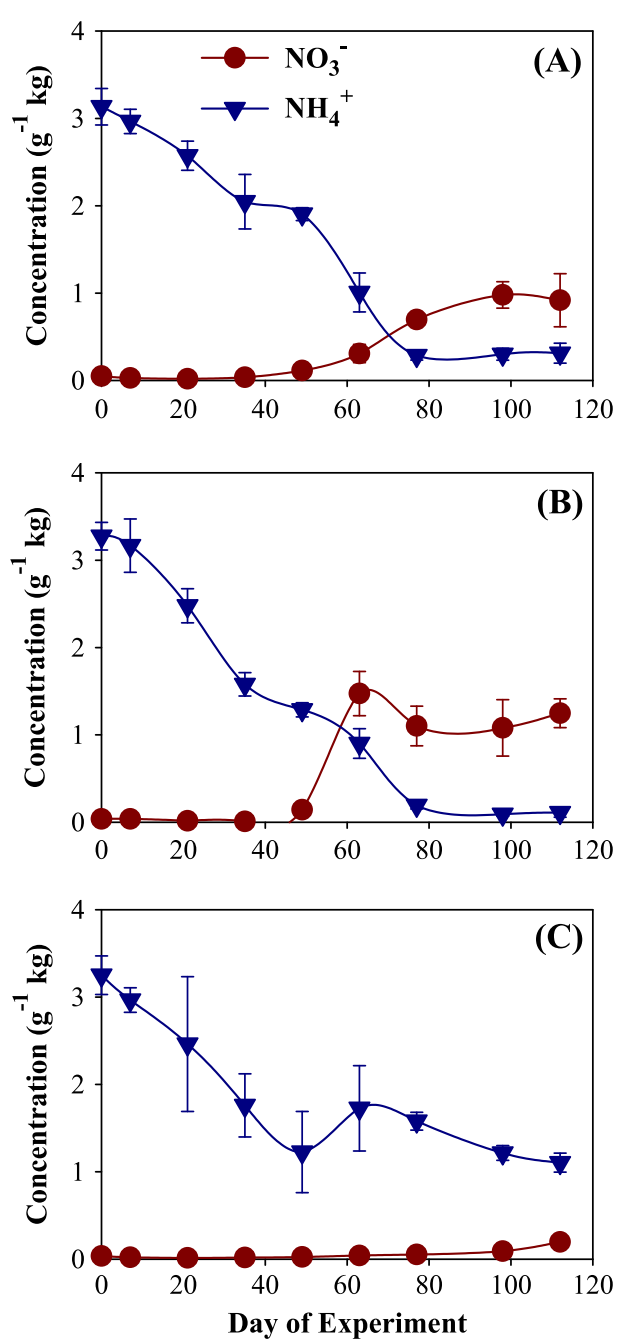

Fig. 2. Ammonium $\left(\mathrm{NH}_{4}^{+}\right)$and nitrate $\left(\mathrm{NO}_{3}^{-}\right)$concentrations in samples taken during the fall compost trial. Piles were turned one time per week (A), three times per week (B) or when pile temperatures reached $65^{\circ} \mathrm{C}(\mathrm{C})$. Values represent the average and standard deviation of three replicate samples. 

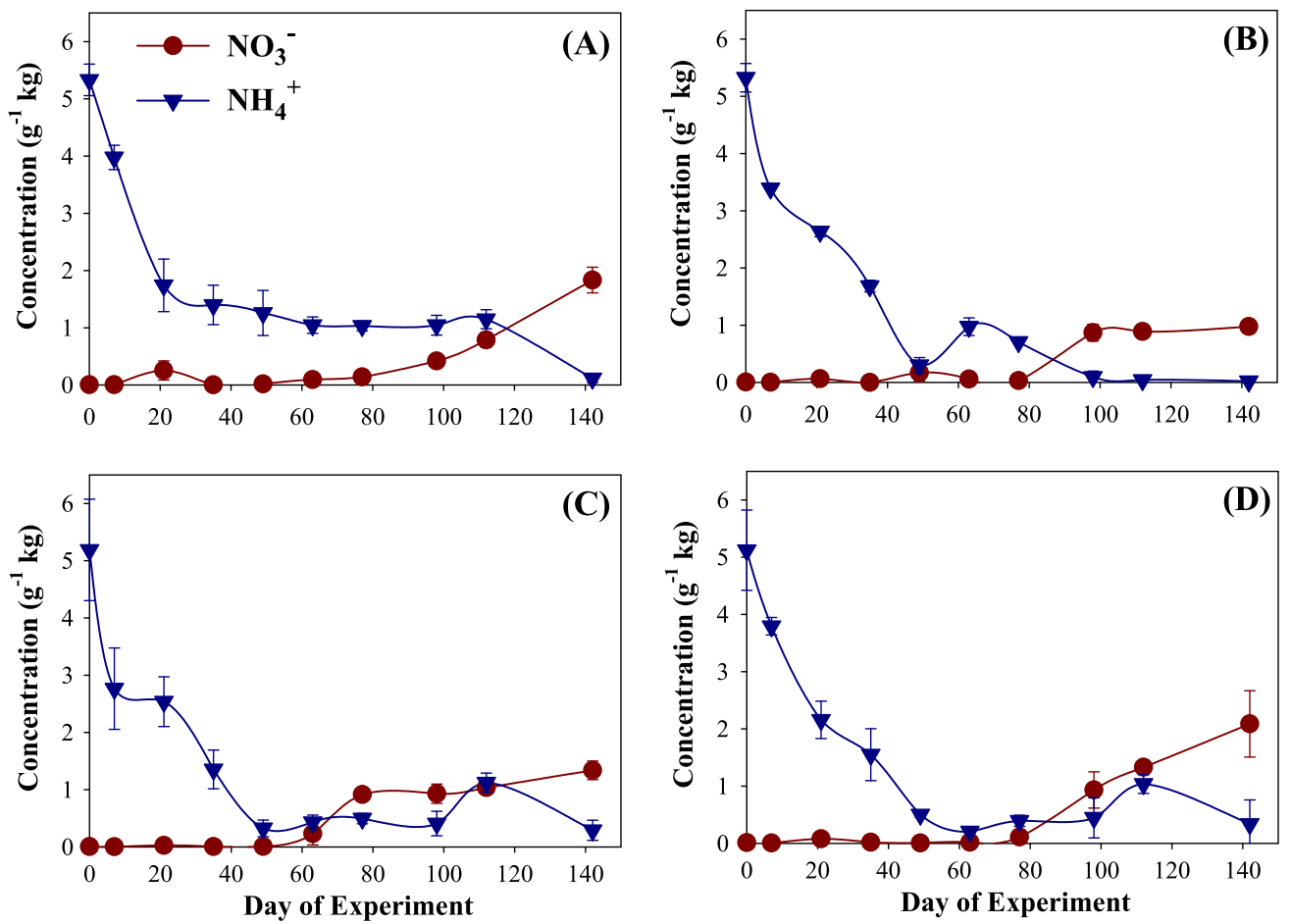

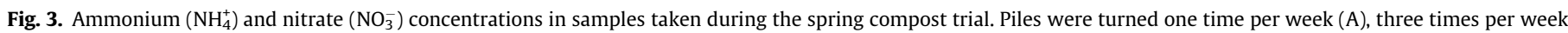
(B), when pile temperatures reached $65^{\circ} \mathrm{C}(\mathrm{C})$, or were left unturned (D). Values represent the average and standard deviation of three replicate samples.

(Table 1). In general, the rate of loss of $\mathrm{NH}_{4}-\mathrm{N}$ was similar among piles regardless of compost season or turning frequency (Figs. 2 and 3). In contrast, total $\mathrm{P}$ increased in all composted materials except for the $3 \times$ pile in the ST (Table 2). Eghball et al. (1997) observed a $0.8 \%$ loss of initial manure $P$ after composting beef feedlot manure, with all of this attributed to runoff of $P$ contained in the leachate. This suggests that $\mathrm{N}$ loss through volatilization was more significant than was the loss through leaching in this study, which is in agreement with others (Eghball et al., 1997; Martins et al., 1992; Somer, 2001). The N:P ratio of the initial slurry-woodchip materials was less than two and did not increase in the final compost for any of the treatments. From the agronomic perspective compost materials with lower N:P ratio (e.g., lower than eight) may not be desirable for repeated land application due to the potential for the buildup of $\mathrm{P}$ in the soil. However, this may not be an issue for application on soils with low initial $\mathrm{P}$ content.

In this study the initial volume of the swine slurry-woodchip mix was reduced by $50-60 \%$. In the FT, there were no differences in volume (i.e., all at 50\%), but in the ST volume reduction occurred in the order $1 \times(60 \%)>3 \times(54 \%)>@ 65(52 \%)$. These values were similar to those of other composted HRFF materials (62-63\%; Frederick et al., 2002) or partially decomposed swine hoop materials (47-57\%; Tiquia et al., 2002). Volume reduction is a significant

Table 5

Cell concentrations at beginning of study (initial) and end of composting in Fall or Spring seasons.

\begin{tabular}{|c|c|c|c|c|c|c|}
\hline \multirow[t]{3}{*}{ Treatment } & \multirow{2}{*}{$\begin{array}{l}\text { Total bacteria }^{a} \\
\text { 16S rRNA }\end{array}$} & \multicolumn{2}{|l|}{ Nitrifiers $^{\mathrm{b}}$} & \multicolumn{3}{|l|}{ Denitrifiers $^{c}$} \\
\hline & & amoA & Arch-amoA & narG & nirK & $\operatorname{nos} Z$ \\
\hline & cells $\mathrm{g}^{-1}$ & & & & & \\
\hline \multicolumn{7}{|l|}{ Fall trial $^{\mathrm{d}}$} \\
\hline Initial & $9.80 \pm 0.15$ & $4.58 \pm 1.17$ & $4.61 \pm 0.44$ & $4.70 \pm 0.46$ & $7.40 \pm 0.13$ & $8.42 \pm 0.14$ \\
\hline $1 \times$ & $9.54 \pm 0.19$ & $3.28 \pm 1.29$ & $6.58 \pm 0.24$ & $4.03 \pm 0.38$ & $7.43 \pm 0.17$ & $8.32 \pm 0.06$ \\
\hline $3 \times$ & $9.42 \pm 0.08$ & $4.41 \pm 0.06$ & $5.49 \pm 0.38$ & $4.54 \pm 0.34$ & $7.58 \pm 0.09$ & $8.26 \pm 0.14$ \\
\hline @65 & $9.49 \pm 0.15$ & $3.61 \pm 1.45$ & $5.67 \pm 0.59$ & $4.33 \pm 0.19$ & $7.41 \pm 0.03$ & $8.07 \pm 0.11$ \\
\hline \multicolumn{7}{|l|}{ Spring trial ${ }^{\mathrm{e}}$} \\
\hline Initial & $10.09 \pm 0.16$ & $3.33 \pm 1.29$ & $3.84 \pm 0.45$ & $4.52 \pm 0.76$ & $7.82 \pm 0.21$ & $8.54 \pm 0.14$ \\
\hline $1 \times$ & $9.76 \pm 0.10$ & $4.73 \pm 0.45$ & $4.91 \pm 0.20$ & $5.07 \pm 0.08$ & $7.48 \pm 0.12$ & $8.29 \pm 0.04$ \\
\hline $3 \times$ & $9.50 \pm 0.07$ & $5.81 \pm 0.11$ & $5.15 \pm 0.07$ & $5.56 \pm 0.23$ & $7.56 \pm 0.09$ & $8.38 \pm 0.08$ \\
\hline @65 & $9.85 \pm 0.02$ & $5.06 \pm 0.12$ & $5.39 \pm 0.23$ & $5.33 \pm 0.13$ & $7.60 \pm 0.02$ & $8.63 \pm 0.06$ \\
\hline $0 \times$ & $9.98 \pm 0.20$ & $3.01 \pm 1.74$ & $4.51 \pm 0.91$ & $5.55 \pm 0.42$ & $7.96 \pm 0.29$ & $8.63 \pm 0.19$ \\
\hline
\end{tabular}

Values are the log of cell concentrations per gram dry weight of compost.

a Total bacteria; quantitiative, real-time PCR (qPCR) assay targeting 16S rRNA gene.

b Nitrifiers; qPCR assay targeting ammonia monoxygenase gene for bacteria $(a m o A)$ or archaea (Arch-amoA).

c Denitrifiers; qPCR assay targeting nitrate reducers (narG), nitrite reducers (nirK) and nitrous oxide reducers (nosZ).

d Fall trial values represent the average \pm standard deviation for triplicate samples taken at start up (initial) or after 112 days from pile turned once a week ( $1 \times$ ), three times a week $(3 \times)$ and once temperature reached $65^{\circ} \mathrm{C}(@ 65)$.

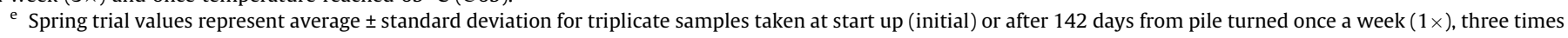
a week $(3 \times)$ and once temperature reached $65{ }^{\circ} \mathrm{C}(@ 65)$, and unturned pile $(0 \times)$. 
advantage of the composting process as it makes this a more readily transportable and marketable product (Bernal et al., 2009; Bustamante et al., 2008; USEPA, 2013). There was no correlation between humic acid (HA) concentrations and turning frequency, but values were higher following the FT than the ST suggesting that compost from the FT had stabilized to a greater extent (Table 1; Bernal et al., 2009).

Organic matter decreased in all FT and ST compost piles regardless of turning regime (Table 1). Less OM was lost in the un-turned compost pile $(0 \times)$ which failed to reach temperatures higher than $34^{\circ} \mathrm{C}$. Carbon losses in that pile were also significantly lower $(>1 \%)$ than in the turned piles (Table 1) suggesting that biodegradation in that pile was lower as was also the case for unturned piles in a study of hoop manure compost conducted by Tiquia et al. (2002). In other respects the unturned pile had properties that were beneficial from an agronomic perspective (i.e., higher total $\mathrm{N}, \mathrm{P}$ and K). Parkinson et al. (2004) suggested that it may be more environmentally (i.e., gaseous emissions, run-off) and economically (more $\mathrm{N}$ retained) judicious to rapidly incorporate livestock wastes into soil rather than composting. However, improperly composted wastes would be more costly to transport (i.e., greater wet weight), less marketable and may contain plant or animal pathogens of concern (Bernal et al., 2009; Tiquia et al., 2000, 2002).

\subsection{Nitrogen dynamics}

In both trials, $\mathrm{NH}_{4}-\mathrm{N}$ loss was high, however, the greatest loss occurred in the $3 \times$ pile which was turned most often (Table 1 ). Aeration rate and turning frequency have been shown to influence nitrogen dynamics through both volatilization and leaching (de Guardia et al., 2008; Parkinson et al., 2004); as was likely the case in this study. However, Fukumoto et al. (2003) found that gas emission rates were also related to the size, scale and temperature of compost piles. Fundamentals of pile scale and structure may account for the similar rate and extent of $\mathrm{NH}_{4}-\mathrm{N}$ lost in the $0 \times$ pile and the turned piles in the ST (Fig. 3).

In the $\mathrm{FT}, \mathrm{NO}_{3}-\mathrm{N}$ concentrations were significantly higher (Table 1) and concentrations increased earlier in piles turned more often (Fig. 2). In the $\mathrm{ST}, \mathrm{NO}_{3}-\mathrm{N}$ concentrations increased at a similar rate in all piles (Fig. 3 ). Interestingly, the $3 \times$ pile had significantly higher $\mathrm{NO}_{3}-\mathrm{N}$ in the FT but had significantly lower $\mathrm{NO}_{3}-\mathrm{N}$ in the ST $(P<0.10$; Table 1$)$; perhaps due to the delayed heating of the pile in the ST. The time at which the compost piles were turned also had an effect on $\mathrm{NO}_{3}-\mathrm{N}$ formation. The pile turned frequently in the first 60 days of composting $\left(\mathrm{FT} @ 65^{\circ} \mathrm{C}\right)$ had significantly less final $\mathrm{NO}_{3}-\mathrm{N}$ than the pile turned more frequently in the final 60 days of composting (ST @6 ${ }^{\circ} \mathrm{C}$; Table 1$)$.

It has been suggested that the increase in $\mathrm{NO}_{3}-\mathrm{N}$ and concomitant increase in the $\mathrm{NH}_{4}-\mathrm{N}: \mathrm{NO}_{3}-\mathrm{N}$ ratio can be used as one indicator of compost maturity (Parkinson et al., 2004; Qian et al., 2014) and in this study that ratio was a robust indicator. The ratio of $\mathrm{NH}_{4}-\mathrm{N}$ to $\mathrm{NO}_{3}-\mathrm{N}$ was between 0.02 and 0.34 for piles turned $1 \times$ or $3 \times$ weekly. The $@ 65{ }^{\circ} \mathrm{C}$ pile turned often in the FT had a final $\mathrm{NH}_{4}-\mathrm{N}$ to $\mathrm{NO}_{3}-\mathrm{N}$ ratio of 5.62 while the same pile turned once weekly in the last 60 days of composting in the ST had a final $\mathrm{NH}_{4}-\mathrm{N}$ to $\mathrm{NO}_{3}-\mathrm{N}$ ratio of 0.22 . The pile turned often in the early stages of composting also had significantly greater $\mathrm{NH}_{4}-\mathrm{N}$ remaining in the final days of composting (Table 1 ). These results suggest that turning frequency, ambient temperature and compost stage at the time of turning all significantly influenced nitrogen dynamics in this compost.

\subsection{Microbiological analysis of nitrifiers and denitrifiers}

To evaluate the relationship between $\mathrm{N}$ dynamics and microbial populations in compost, we measured concentrations of two important functional groups: denitrifiers and nitrifiers. Denitrifiers are responsible for reduction of nitrate to molecular nitrogen $\left(\mathrm{N}_{2}\right)$; these populations are diverse and ubiquitous in the environment. In these composts, concentrations of denitrifiers were similar in FT and ST composts and there were no significant differences in concentrations between samples regardless of turning frequency, compost time or season (Table 5). This is in contrast to findings of Angnes et al. (2013) and Wang et al. (2013) which showed that concentrations of genes for denitrification (i.e., norB, nosZ, nirK and nirS) varied over the course of composting and that the concentrations were correlated with $\mathrm{N}_{2} \mathrm{O}$ emissions in swine slurry composts. These HRFF materials had been accumulated/ stored and partially decomposed while under the high-rise facilities for two to three months prior to composting, likely permitting accumulation of denitrifiers and accounting for higher concentrations in the initial compost materials. The lack of production of $\mathrm{NH}_{4}-\mathrm{N}$ over the course of composting, high initial $\mathrm{NH}_{4}-\mathrm{N}$ concentrations in HRFF materials and the steady decline in $\mathrm{NH}_{4}-\mathrm{N}$ in all compost piles also suggest that denitrification had already occurred to a large extent while the material was under the HRFF.
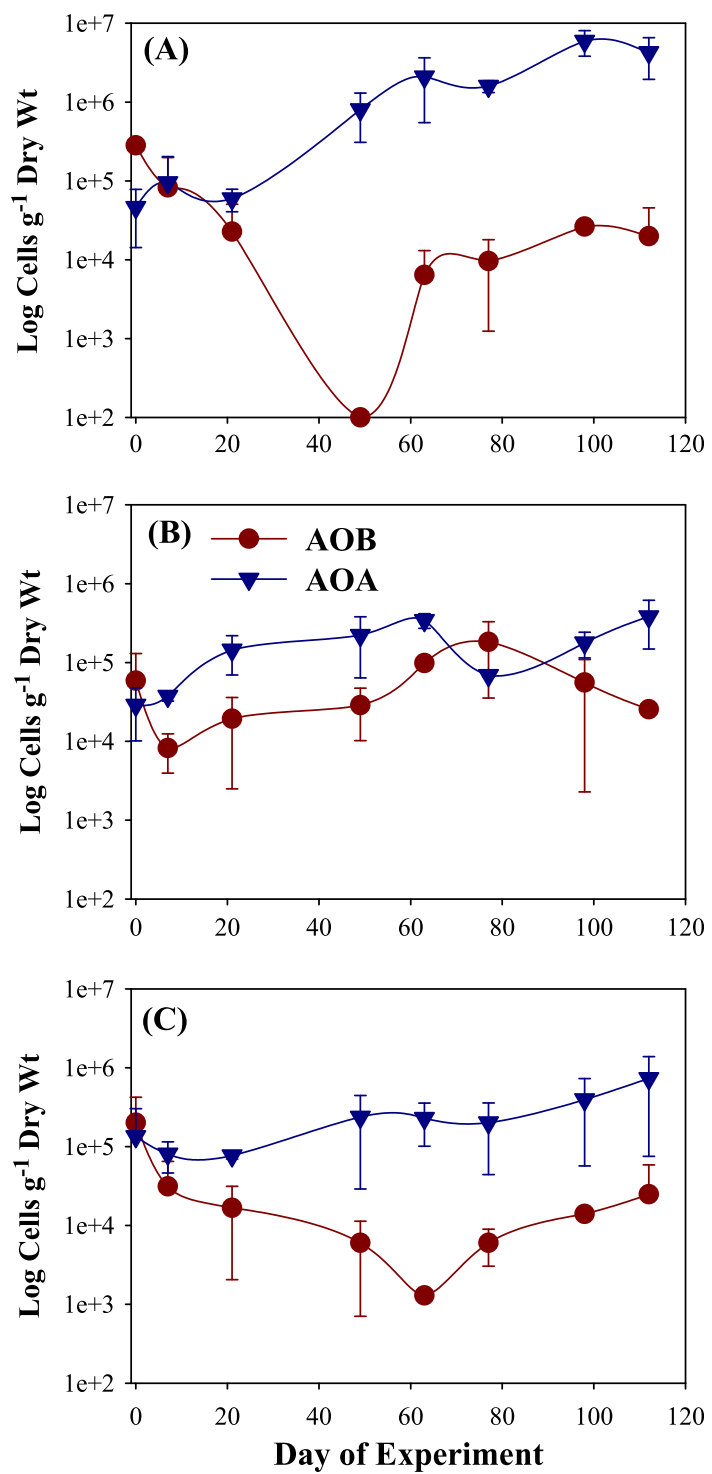

Fig. 4. Concentration of ammonia oxidizing bacteria (AOB) and ammonia oxidizing archaea (AOA) in samples taken during the fall compost trial from piles turned one time per week (A), three times per week (B) or when pile temperatures reached $65{ }^{\circ} \mathrm{C}(\mathrm{C})$. Values represent the average and standard deviation of three replicate samples. 

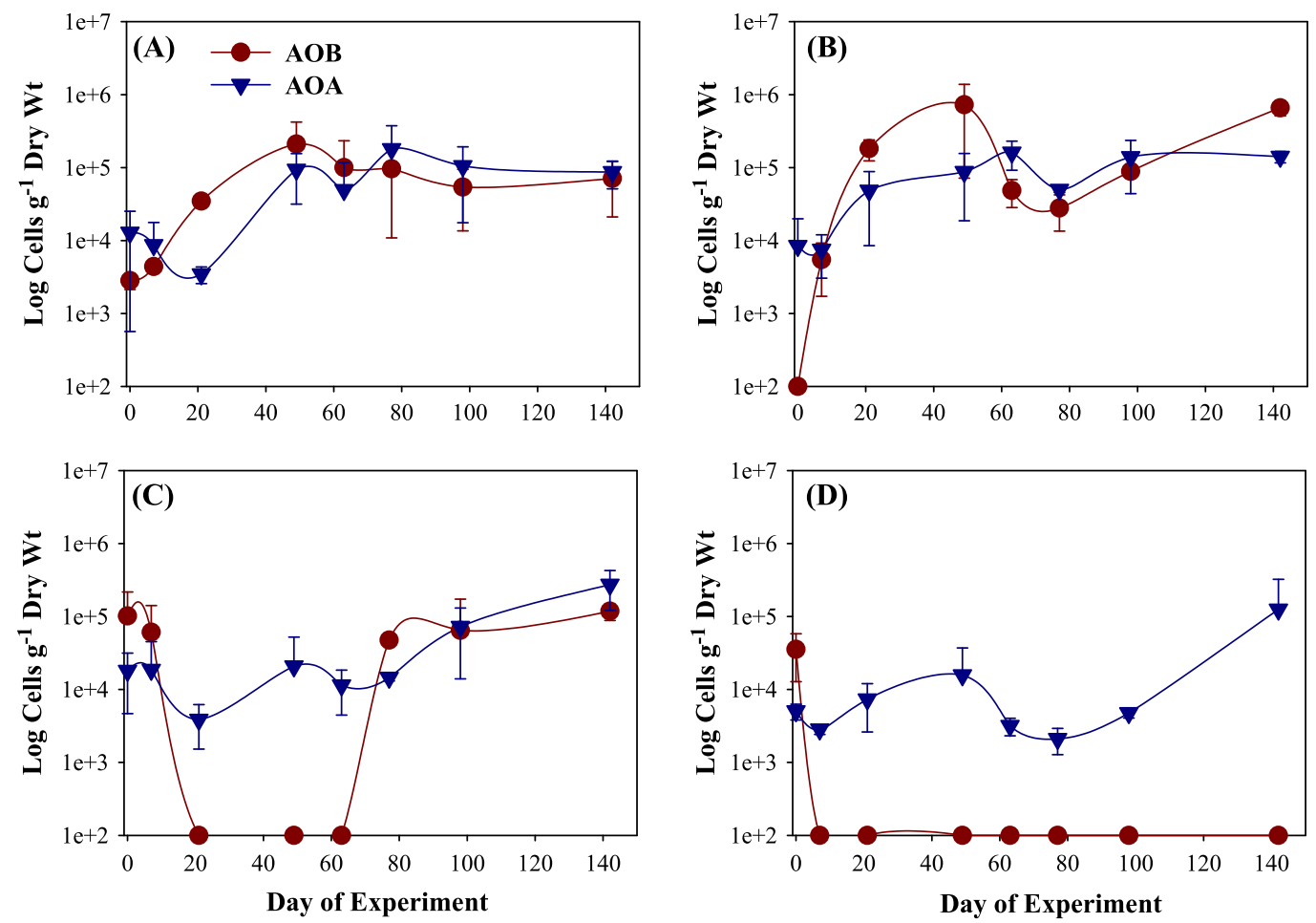

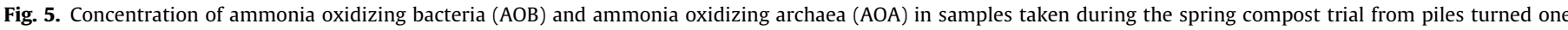

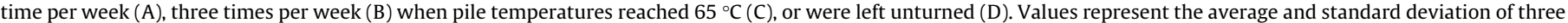
replicate samples.

Nitrifiers, responsible for oxidation of ammonia to nitrate, consist of two phylogenetically diverse groups of organisms, ammonia oxidizing bacteria (AOB) and ammonia oxidizing archaea (AOA). There were significantly lower concentrations of AOA and AOB in initial materials from the ST than were present in materials obtained for the FT (Table 5). Given that this material was under the HRFF for several months prior to removal for finishing, it is possible that the cooler temperatures in the months prior to removal resulted in lower concentrations of nitrifiers in material obtained for the ST. It is also possible that HRFF materials were not turned as routinely in the months prior to removal from under the facility, leading to more anaerobic conditions and lower concentrations of nitrifiers. This is supported by the significantly higher concentration of $\mathrm{NH}_{4}-\mathrm{N}$ in the material obtained for the ST.

AOA concentrations were the same or higher than AOB in both compost trials and regardless of turning frequency (Figs. 4 and 5). Yamamoto et al. (2010) also found that cattle manure compost was dominated by $A O A$, despite persistence of $A O B$ throughout the thermophilic phase of composting. In other studies, AOB were found to be dominant (Yamada et al., 2013; Yamamoto et al., 2012). Authors speculate that differences in temperature, oxygen and initial $\mathrm{NH}_{4}-\mathrm{N}$ concentration may all contribute to dominance of one group of nitrifiers over another (Yamada et al., 2013; Yamamoto et al., 2010, 2012; Zeng et al., 2011).

In the ST, the pile that was never turned had AOB concentrations that were below detection limits throughout the course of the study (Fig. 5D). Similarly, the @6 ${ }^{\circ} \mathrm{C}$ pile which was not turned until day 60 had no detectable AOB until after turning was initiated (Fig. 5C). In both piles concentrations of AOA remained above detection limits regardless of turning. In the $0 \times$ pile, nitrate formation occurred despite the lack of detectable AOB (Fig. 3D). These results suggest that aeration was needed to stimulate growth of $\mathrm{AOB}$ and that $\mathrm{AOA}$ were responsible for nitrate formation in unturned piles. However, significant increases in the concentration of $A O B$ in the final stages of composting in the FT and over the course of composting in the ST suggest that AOB survived the high temperatures of composting. Zeng et al. (2011) found that AOA dominated in their agricultural waste compost during thermophilic and cooling stages, while the activity of AOB correlated with ammonia oxidation during mesophilic and maturation stages. Our results also suggest that both groups of nitrifiers contributed to nitrification and their relative importance was difficult to predict in compost piles that were routinely turned.

\section{Conclusions}

Composting of swine slurry on large-scale production facilities in the U.S. is rare in part due to the need to convert liquid slurries to solids. The HRFF model provides an alternative to liquid waste treatment systems; slurries are converted to solids as part of the production process and materials are partially decomposed under the facility. Results from these studies show that the partially decomposed swine slurry-woodchip mixes from these swine HRFF are readily composted despite low initial $\mathrm{C} / \mathrm{N}$ and regardless of turning schedule or ambient conditions. Although $\mathrm{N}$ losses were significant, the large volume and moisture reduction and low readily degradable OM levels suggest that the finished compost would have lower transportation costs than either liquid slurries or uncomposted HRFF slurry-woodchip mixtures. Results suggest that the finished compost would provide value as a soil amendment or conditioner, but studies are warranted to evaluate its agronomic value as an alternative source of plant nutrients.

\section{Acknowledgements}

The authors thank Stacy Antle, Derrek Brown, Rohan Parekh and Jason Simmons for valuable technical assistance. The authors also 
thank O’Bryan Grain Farms. Inc. for providing access to facilities, materials, and equipment in support of this experiment. This research was conducted as part of USDA-ARS National Program 214: Agricultural and Industrial By-products: CRIS 6445-12630004-00D. Mention of trade names or commercial products in this article is solely for the purpose of providing specific information and does not imply recommendation or endorsement by the USDA.

\section{References}

Aita, C., Recous, S., Cargnin, R.H.O., da Luz, L.P., Giacomini, S.J., 2012. Impact on C and $\mathrm{N}$ dynamics of simultaneous application of pig slurry and wheat straw, as affected by their initial locations in soil. Biol. Fertility Soils 48, 633-642.

Angnes, G., Nicoloso, R.S., da Silva, M.L.B., de Oliveira, P.A.V., Higarashi, M.M., Mezzari, M.P., Miller, P.R.M., 2013. Correlating denitrifying catabolic genes with $\mathrm{N}_{2} \mathrm{O}$ and $\mathrm{N}_{2}$ emissions from swine slurry composting. Bioresour. Technol. 140, $368-375$.

Bernal, M.P., Alburquerque, J.A., Moral, R., 2009. Composting of animal manures and chemical criteria for compost maturity assessment. A review. Bioresour. Technol. 100, 5444-5453.

Bustamante, M.A., Paredes, C., Marhuenda-Egea, F., Perez-Espinosa, A., Bernal, M.P., Moral, R., 2008. Co-composting of distillery wastes with animal manures: carbon and nitrogen transformations in the evaluation of compost stability. Chemosphere 72, 551-557.

Bustamante, M.A., Restrepo, A.P., Alburquerque, J.A., Perez-Murcia, M.D., 2013. Recycling of anaerobic digestates by composting: effect of the bulking agent used. J. Cleaner Prod. 47, 61-69.

Ciavatta, C., Govi, M., Pasotti, L., Sequi, P., 1993. Changes in organic matter during stabilization of compost from municipal solid wastes. Bioresour. Technol. 43 $141-145$.

Cook, K.L., Netthisinghe, A.M.P., Gilfillen, R.A., 2014. Detection of pathogens, indicators and antibiotic resistance genes following land application of poultry litter. J. Environ. Qual. 43, 1546-1558.

de Guardia, A., Petiot, C., Rogeau, D., Druilhe, C., 2008. Influence of aeration rate on nitrogen dynamics during composting. Waste Manage. 28, 575-587.

Derby, N.E., Hakk, H., Casey, F.X.M., DeSutter, T.M., 2011. Effects of composting swine manure on nutrients and estrogens. Soil Sci. 176, 91-98.

Eghball, B., Power, J.F., Gilley, J.E., Doran, J.W., 1997. Nutrient, carbon, and mass loss during composting of beef cattle feedlot manure. J. Environ. Qual. 26, 189-193.

Eghball, B., Ginting, D., Gilley, J.E., 2004. Residual effects of manure and compost application on corn production and soil properties. Agron. J. 96, 442-447.

Francis, C.A., Roberts, K.J., Beman, J.M., Santoro, A.E., Oakley, B.B., 2005. Ubiquity and diversity of ammonia-oxidizing archaea in water columns and sediments of the ocean. PNAS 102, 14683-14688.

Frederick, C.M.J., Sun, H., Pecchia, J., Keener, H.M., 2002. Nutrient balance analysis for finishing hog production: high-rise hog vs. conventional deep pit systems, ASAE paper 024145, ASAE, Chicago, IL.

Fukumoto, Y., Inubushi, K., 2009. Effect of nitrite accumulation on nitrous oxide emission and total nitrogen loss during swine manure composting. Soil Sci. Plant Nut. 55, 428-434.

Fukumoto, Y., Osada, T., Hanajima, D., Haga, K., 2003. Patterns and quantities of $\mathrm{NH}_{3}$ $\mathrm{N}_{2} \mathrm{O}$ and $\mathrm{CH}_{4}$ emissions during swine manure composting without forced aeration - effect of compost pile scale. Bioresour. Technol. 89, 109-114.

Harms, G., Layton, A.C., Dionisi, H.M., Gregory, I.R., Garrett, V.M., Hawkins, S.A. Robinson, K.G., Sayler, G.S., 2003. Real-time PCR quantification of nitrifying bacteria in a municipal wastewater treatment plant. Environ. Sci. Technol. 37, 343-351.

Hong, N., Chen, J., Gao, D., Chen, T.B., Zhang, X.H., Cai, L., 2014. Enhanced water reduction by turning during sewage sludge composting. J. Chem. Technol. Biotechnol. 89, 756-762.

Keener, H.M., Elwell, D.L., Ekinci, K., Hoitink, H.A.J., 2001. Composting \& value-added utilization of manure from a high-rise ${ }^{\mathrm{TM}}$ swine finishing facility. Compost Sci. Utiliz. 9, 312-321.

Kenney, D.R., Nelson, D.W., 1982. Nitrogen - inorganic forms, in: al., A.L.P.e. (Ed.) Methods of soil analysis, Part 2. Agron. Monogr. 9. 2nd ed. ASA and SSSA Madison, WI, pp. 643-698

Key, N., McBride, W.D., Ribaudo, M., Sneeringer, S., 2011. Trends and Developments in Hog Manure Management: 1998-2009. US Dept. of Agriculture, Washington, D.C., pp. 1-39.

Kuok, F., Mimoto, H., Nakasaki, K., 2012. Effects of turning on the microbia consortia and the in situ temperature preferences of microorganisms in a laboratory-scale swine manure composting. Bioresour. Technol. 116, 421-427.

Larney, F.J., Hao, X., 2007. A review of composting as a management alternative for beef cattle feedlot manure in southern Alberta, Canada. Bioresour. Technol. 98 3221-3227.

Larney, F.J., Olson, A.F., Carcamo, A.A., Chang, C., 2000. Physical changes during active and passive composting of beef feedlot manure in winter and summer. Bioresour. Technol. 75, 139-148.

Lee, C.H., Wu, M.Y., Asio, V.B., Chen, Z.S., 2006. Using a soil quality index to assess the effects of applying swine manure compost on soil quality under a crop rotation system in Taiwan. Soil Sci. 171, 210-222.

Martins, O., Dewes, T., 1992. Loss of nitrogenous compounds during composting of animal wastes. Bioresour. Technol. 42, 103-111.
Mc Carthy, G., Lawlor, P.G., Coffey, L., Nolan, T., Gutierrez, M., Gardiner, G.E., 2011. An assessment of pathogen removal during composting of the separated solid fraction of pig manure. Bioresour. Technol. 102, 9059-9067.

McAndrews, G.M., Liebman, M., Cambardella, C.A., Richard, T.L., 2006. Residual effects of composted and fresh solid swine (Sus scrofa L.) manure on soybean [Glycine max (L.) Merr.] growth and yield. Agron. J. 98, 873-882.

Nolan, T., Troy, S.M., Healy, M.G., Kwapinski, W., Leahy, J.J., Lawlor, P.G., 2011. Characterization of compost produced from separated pig manure and a variety of bulking agents at low initial C/N ratios. Bioresour. Technol. 102, 7131-7138.

Pan, X., Qiang, Z.M., Ben, W.W., 2013. Effects of high-temperature composting on degradation of antibiotics in swine manure. J. Ecol. Rural Environ. 29, 64-69.

Parkinson, R., Gibbs, P., Burchett, S., Misselbrook, T., 2004. Effect of turning regime and seasonal weather conditions on nitrogen and phosphorus losses during aerobic composting of cattle manure. Bioresour. Technol. 91, 171-178.

Qian, X., Shen, G., Wang, Z., Guo, C., Liu, Y., Lei, Z., Zhang, Z., 2014. Co-composting of livestock manure with rice straw: characterization and establishment of maturity evaluation system. Waste Manage. 34, 530-535.

Ros, M., García, C., Hernández, T., 2006. A full-scale study of treatment of pig slurry by composting: kinetic changes in chemical and microbial properties. Waste Manage. 26, 1108-1118.

Selvam, A., Zhao, Z., Wong, J.W., 2012. Composting of swine manure spiked with sulfadiazine, chlortetracycline and ciprofloxacin. Bioresour. Technol. 126, 412417.

Shane, E.M., Endres, M.I., Johnson, D.G., Reneau, J.K., 2010. Bedding options for an alternative housing system for dairy cows: a descriptive study. Appl. Eng. Agric. 26, 659-666.

Sharifi, M., Zebarth, B.J., Miller, J.J., Burton, D.L., Grant, C.A., 2014. Soil nitrogen mineralization in a soil with long-term history of fresh and composted manure containing straw or wood-chip bedding. Nutr. Cycl. Agroecosyst. 99, 63-78.

Sistani, K.R., Warren, J.G., Lovanh, N., Higgins, S., Shearer, S., 2010. Greenhouse gas emissions from swine effluent applied to soil by different methods. SSSAJ 74, 429-435.

Smith, C.J., Nedwell, D.B., Dong, L.F., Osborn, A.M., 2007. Diversity and Abundance Of Nitrate Reductase Genes (narG and napA), nitrite reductase genes (nirS and $\operatorname{nrfA}$ ), and their transcripts in estuarine sediments. Appl. Environ. Microbiol. 73, 3612-3622.

Somer, S.G., 2001. Effect of composting on nutrient loss and nitrogen availability of cattle deep litter. Eur. J. Agron. 14, 123-133.

Stowell, R.R., 2002. Applicability of high-rise(TM) hog housing for finishing operations. Nebraska Swine Rep., 54-59

Ten Hoeve, M., Hutchings, N.J., Peters, G.M., Svanström, M., Jensen, L.S., Bruun, S., 2014. Life cycle assessment of pig slurry treatment technologies for nutrient redistribution in Denmark. J. Environ. Manage. 132, 60-70.

Throback, I.N., Enwall, K., Jarvis, A., Hallin, S., 2004. Reassessing PCR primers targeting nirS, nirK and nosZ genes for community surveys of denitrifying bacteria with DGGE. FEMS Microbiol. Ecol. 49, 401-417.

Tiquia, S.M., 2005. Microbiological parameters as indicators of compost maturity. J. Appl. Microbiol. 99, 816-828.

Tiquia, S.M., Richard, T.L., Honeyman, M.S., 2000. Effect of windrow turning and seasonal temperatures on composting of hog manure from hoop structures. Environ. Technol. 21, 1037-1046.

Tiquia, S.M., Richard, T.L., Honeyman, M.S., 2002. Carbon, nutrient, and mass loss during composting. Nutr. Cycl. Agroecosyst. 62, 15-24.

Tirado, S.M., Michael, F.C., 2010. Effects if turning frequency, windrow size and season on the production of dairy manure/sawdust composts. Compost Sci. Utiliz. 18, 70-80.

USEPA, 2004. Risk Management Evaluation for Concentrated Animal Feeding Operations. U.S. Environmental Protection Agency, Washington, D.C., p. 138.

USEPA, 2013. Literature Review of Contaminants in Livestock and Poultry Manure and Implications for Water Quality. U.S. Environmental Protection Agency, Washington, D.C., p. 137.

Wang, P., Changa, C.M., Watson, M.E., Dick, W.A., Chen, Y., Hoitink, H.A.J., 2004. Maturity indices for composted dairy and pig manures. Soil Biol. Biochem. 36, 767-776.

Wang, C., Lu, H., Dong, D., Deng, H., Strong, P.J., Wang, H., Wu, W., 2013. Insight into the effects of biochar on manure composting: Evidence supporting the relationship between $\mathrm{N}_{2} \mathrm{O}$ emission and denitrifying community. Environ. Sci. Technol. 47, 7341-7349.

Yamada, T., Araki, S., Ikeda-Ohtsubo, W., Okamura, K., Hiraishi, A., Ueda, H., Ueda, Y., Miyauchi, K., Endo, G., 2013. Community structure and population dynamics of ammonia oxidizers in composting processes of ammonia-rich livestock waste. Syst. Appl. Microbiol. 36, 359-367.

Yamamoto, N., Otawa, K., Nakai, Y., 2010. Diversity and abundance of ammoniaoxidizing bacteria and ammonia-oxidizing archaea during cattle manure composting. Microb. Ecol. 60, 807-815.

Yamamoto, N., Oishi, R., Suyama, Y., Tada, C., Nakai, Y., 2012. Ammonia-oxidizing bacteria rather than ammonia-oxidizing archaea were widely distributed in animal manure composts from field-scale facilities. Microb. Environ. 27, 519524.

Zeng, G., Zhang, J., Chen, Y., Yu, Z., Yu, M., Li, H., Liu, Z., Chen, M., Lu, L., Hu, C., 2011. Relative contributions of archaea and bacteria to microbial ammonia oxidation differ under different conditions during agricultural waste composting. Bioresour. Technol. 102, 9026-9032.

Zhong, J., Wei, Y., Wan, H., Wu, Y., Zheng, J., Han, S., Zheng, B., 2013. Greenhouse gas emission from the total process of swine manure composting and land application of compost. Atmos. Environ. 81, 348-355. 